\title{
Homosexual Desire and Gender Bending in Pardo Bazán's Los Pazos de Ulloa
}

\author{
Daniel Ferreras Savoye
}

(WEST VIRGINIA UNIVERSITY)

\section{RESUMEN}

A pesar de haber recibido considerable atención por parte de la crítica, Los Pazos de Ulloa, sin duda una de las novelas más famosas de Emilia Pardo Bazán, no ha sido examinada desde el punto de vista de su representación del deseo homosexual. A partir de un análisis minucioso del texto, este ensayo demuestra cómo se manifiesta la homosexualidad latente del personaje principal, don Julián, su amor hacia el dueño de los Pazos, don Pedro, a través de motivos narrativos espécificos que participan de lleno a la progresión del sintagma narrativo y refuerzan la coherencia de su estructura semiótica.

PALABRAS CLAVE: Pardo Bazán, Los Pazos de Ulloa, deseo homosexual, transgresión de género, lectura semiótica.

\section{ABSTRACT}

In spite of having received considerable critical attention, Emilia Pardo Bazán's wellknown novel Los Pazos de Ulloa has not yet been examined from the point of view of its representation of homosexual love and desire. By closely examining the text, this essay shows how the latent homosexuality of the main protagonist, Julián, and his unspoken desire for his master, don Pedro, are not only fundamental motifs but also key factors in the progression of the narrative structure and participate fully in its coherence.

KEY WORDS: Pardo Bazán, Los Pazos de Ulloa, Homosexual desire, gender transgression, meaning semiotic. 
It is surprising not to find the name of Emilia Pardo Bazán in Foster's biocritical sourcebook, Spanish Writers on Gay and Lesbian Themes ${ }^{\mathrm{I}}$, for her pronounced gender consciousness as a writer as well as a critic has been the object of several studies, such as those of Wietelmann Bauer and Harpring, both concerned with the representation of cross-dressing in Memorias de un solterón, and those by Tolliver, Kirkpatrick, Bieder and Hart, which explore the different manifestations of gender and genderization in her texts ${ }^{2}$. From a meta-critical point of view, Dupont's essay on "Decadence, Women Writers, and Literary History in Emilia Pardo Bazán's Late Criticism" clearly illustrates Pardo Bazán's preoccupation with gender construction and the possibility of its transcendence, as demonstrated by her reflections on George Sand and Oscar Wilde ${ }^{3}$.

The character of Julián, the main protagonist of what could be considered as Pardo Bazán's most important work ${ }^{4}$, Los Pazos de Ulloa, is highly representative of this textual gender indeterminacy, and his feminine qualities are abundantly mentioned within the text itself. For Feal Deibe, Julián is "una especie de puente entre actitudes feministas y anti-feministas, lo que

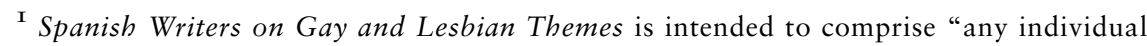
who, although not dealing overtly with a gay topic or professing a gay identity, has authored works in which something like a gay sensibility can be indentified (including any aspect that can be associated with the questioning of binary sexuality and compulsory heterosexuality)" (Foster 1999: ix). The all inclusive scope of the volume allows its authors to explore the connections between figures as remotely associated to homosexuality as can be Ortega y Gasset or Santa Teresa de Avila, hence rendering the absence of Pardo Bazán all the more puzzling.

2 Wietelmann Bauer (1994): "Narrative Cross-Dressing: Emilia Pardo Bazán in Memorias de un solterón"; Harpring (2006): "Homoeroticism and Gender Role Confusion in Pardo Bazán’s Memorias de un solterón"; Tolliver (1994) and Kirkpatrick (1999) examine gender issues in “'Sor Aparición’ and the Gaze: Pardo Bazán’s Gendered Reply to the Romantic Don Juan" and "Gender and Modernist Discourse: Emilia Pardo Bazán's Dulce Dueño" respectively, while Bieder (1990) explores the author's constant negotiation with her historical patriarchal context and the gendered markings of Realism and Naturalism in "Between Genre and Gender: Pardo Bazán and Los Pazos de Ulloa"; Hart's essay (2009), "The Gendered Gothic in Pardo Bazán's Los Pazos de Ulloa" proposes a reading of the novel based upon the notion of the Gothic as established by Sedgwick, which includes a re-distribution of gender roles.

3 Pardo Bazán: El lirismo en la poesía francesa, qtd. in Dupont 2002: 350-51; 357-58.

4 This evaluation is not to be taken, naturally, as a value judgment, and no one could deny the significance of La Tribuna, or of Insolación, both stylistically and ideologically. Even Viaje de Novios, Pardo Bazán's second novel, is worthy of critical attention, and could be compared, in terms of feminine/feminist referent to Flaubert's Madame Bovary as well as to Maupassant's Une Vie. Nevertheless, Los Pazos de Ulloa remains to this day Pardo Bazán's most re-edited and distributed novel. 
explicaría la actitud ambivalente que suscita en la narradora, quien a la vez simpatiza con él y se burla de él" (Feal Deibe 1987: 216), a notion which is repeated in Llácer: "En este sentido, Julián actúa de puente, desde un punto de vista semiótico, entre el mundo masculino y femenino, ya que siendo hombre, es también algo 'afeminado'" (Llácer 1991: 434-35). Indeed, Julián's gender ambivalence is "semiotic," i.e., meaningful, however Llácer does not go any further in his development, and his essay remains within the boundaries of Feal Deibe's, who uses Bakhtin's concept of heteroglossia to interpret the diversity of narrative voices found in the novel (Feal Deibe 1987: 216 ${ }^{5}$. Beyond the traditional gender dichotomy of masculine/feminine, I propose to show that Julián's effeminate aspects are the external signs of a latent homosexual desire towards don Pedro, the handsome and utterly virile Marquis of Ulloa, an attraction which determines key moments of the narration throughout Los Pazos de Ulloa, and evolves into a clear example of gender bending in its continuation, La Madre Naturaleza. The reading of Julián as experiencing homosexual desire towards don Pedro rather than functioning as an ambivalent, androgyne character or simply as a Nucha's stand-in allows us to perceive a higher level of coherence in the narration for it offers a logical explanation for some of his most problematic decisions, which in turn dramatically affect both the evolution of the other characters and that of the narrative universe. Julián's subconscious attraction towards don Pedro determines the future of Nucha and don Pedro as well as his own, and ultimately betrays his conscious efforts to reform the House of Ulloa.

\footnotetext{
5 "This latecomer [heteroglossia] reflects, in its stylistic structure, the struggle between two tendencies in the languages of European peoples: one a centralizing (unifying) tendency, the other a decentralizing tendency (that is, one that stratifies languages). The novel senses itself on the border between the completed, dominant literary language and the extraliterary languages that know heteroglossia" (Bakhtin 1981: 67). Although Bakhtin is more concerned with social types of languages as reflected by different levels of speech than with gender differentiation, his concept is indeed applicable to the different narrative voices at play throughout the text of Los Pazos de Ulloa. What appears more questionable is Feal Deibe's affirmation, repeated by Llácer, that these intratextual dialogs indirectly expose the author's intentions (1987: 217); it seems more appropriate to speak of the text's intentions and to distinguish between the historical author, i.e., Emilia Pardo Bazán writing Los Pazos in the late eighties of the nineteenth century, and the abstract author, i.e., Pardo Bazán as an authorial presence reflected in the text. In our discussion, textual heteroglossia includes a homosexual voice, whether it was intended by the historical author or not. (For further development on the question of historical/abstract author, see Lindvelt (1981): Le Point de vue: essai de typologie narrative).
} 
My analysis will be solely textual, for we find within the text itself the semiotic elements that can lead us towards a re-evaluation of Julián's significance and function as a homosexual presence in relation to the narrative syntagm.

The initial description of Julián, as he tries to control his horse on his way to the House of Ulloa already suggests his femininity: "Iba el jinete colorado, no como un pimiento sino como una fresa, encendimiento propio de personas linfáticas. Por ser joven y de miembros delicados, y por no tener pelo de barba, parecia un niño, a no desmentir la presunción de sus trazas sacerdotales" (Pardo Bazán 1985: 7). Solanas quotes this very paragraph in his "Estructura y simbolismo en Los Pazos de Ulloa" but omits the words "no como un pimiento, sino como una fresa," and isolates the proposition "personas linfáticas" to better serve his analysis, mainly based upon the psychological evolution of what he calls "la mente desequilibrada de Don Julián" (Solanas 1981: 199). However, this binary opposition is highly symbolic, for not only is "pimiento" masculine and "fresa" feminine, but each refers to equally gendered connotations, in terms of shape and consistency; the delicate strawberry appears indeed more feminine than the rugged pepper. Furthermore, the syntactic organization of the sentence underlines this array of feminine connotations by placing the negation first, which increases the tension of the proposition by delaying its referential delivery, and naturally solicits the attention of the destinatary: it becomes grammatically significant that Julián resembles a strawberry by opposition to a pepper ${ }^{6}$. The absence of beard conveys a corresponding semiotic content and should be opposed to its very presence as a representative metonymy of don Pedro, whom Julián meets for the first time a few pages later: "El cazador que venía delante representaba veintiocho o treinta años: alto y bien barbado, tenía el pescuezo y rostro quemados del sol" (Pardo Bazán 1985: 12). Just as a pepper can be opposed to a strawberry in terms of gendered connotations, Julián's lack of facial hair can be understood in function of don Pedro's full beard. By metonymic transition, the description of don Pedro includes other instances of hair, which in turn become erotically significant: "pero por venir despechugado y sombrero en mano se advertía la blancura de la piel no expuesta a la intemperie, en la frente y en la tabla del pecho, cuyos diámetros indicaban

6 The Cuban film, Fresa y chocolate, directed by Tomás Gutiérrez Alea and Juan Carlos Tabío, associates in a more recent context the paradigm of the strawberry with homosexual desire. 


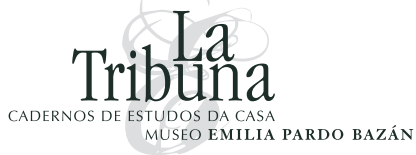

complexión robusta, supuesto que confirmaban la isleta de vello rizoso que dividía ambas tetillas" (Pardo Bazán 1985: 12). The nipples are indeed sexually charged elements and they are in this case related to the chest hair, an obvious symbol of virility, and thus, this initial description emphasizes don Pedro's attractive physical qualities from an objective point of view, which corresponds to that of an omniscient narrator. However, as pointed out by Maryellen Bieder, different narrative focalizers are at play in Los Pazos de Ulloa for "the narration itself largely is filtered through the subjectivity of the characters" (Bieder 1990: 133), and we observe a shift of focalization in the narrative discourse when Julián and don Pedro finally introduce themselves to one another. Julián becomes the focalizer and his first considerations echo the objective description of don Pedro introduced earlier by the omniscient narrator by insisting as well upon his physical attractiveness: “... el capellán le miraba con interés rayano en viva curiosidad. No hay duda que así, varonilmente desaliñado, húmeda la piel de transpiración ligera, terciada la escopeta al hombro, era un cacho de mozo el marqués" (Pardo Bazán 1985: 13). It must be underlined that this supplementary description of don Pedro's physical appearence is introduced as Julián is looking at him "con interés rayano en viva curiosidad (Pardo Bazán 1985): "the omniscient narrator has yielded to the character's particular perspective, and hence this particular textual moment reflects Julián's personal perception of don Pedro. The words "húmeda la piel de transpiración ligera" suggest an erotic component to this encounter as seen by and textualized through Julián as the main focalizer, which is easily completed by the phallic symbol that the rifle represents; Julián is therefore directly aroused by the handsome aspect of don Pedro ${ }^{7}$.

The fascination of Julián with don Pedro's physical aspect is directly proportional to his immediate dislike of Sabel, don Pedro's servant and lover, whom he meets as soon as he arrives at the Pazos, and is based as well on her physical aspect: "Lo cierto es que Julián bajaba la vista, no tanto por lo que oía como por no ver a Sabel, cuyo aspecto desde el primer instante

7 According to Bieder, "In addition to its conventional male voice, the narration [in Los Pazos de Ulloa] frequently narrows to follow the gaze and emotional responses of a gendered focalizer" (1990: 133). Such discursive phenomenon can be observed in this particular scene as we follow Julián's gaze and are informed of his emotional, erotically charged response. This shift in focalizer becomes all the more significant when we oppose it to the "assertively male-voiced narrative conventions and the privileging of male culture" (Bieder 1990: 133) also present in the novel, for it implies that the text must break free form conventional male-dominated literary discourse in order to express the desire Julián feels towards don Pedro.

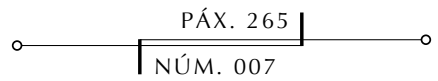


le había desagradado de extraño modo, a pesar o quizá a causa de que Sabel era un buen pedazo de lozanísima carne" (Pardo Bazán 1985: 21). The parallelism of both narrative instances -both scenes are first encounters and presented in relationship to Julián's gaze- as well as of the physical qualities of don Pedro and Sabel is reflected by the choice of equivalent expressions, for don Pedro is a "cacho de mozo" (Pardo Bazán 1985: 13) and Sabel, a "pedazo de lozanísima carne" (Pardo Bazán 1985: 21). "Cacho" and "pedazo" are synonyms and both imply a disappearance of individual identity behind a generic notion, which in this case emphasizes exclusively physical characteristics and turns the subject into an object of desire. And whereas Julián was utterly interested in don Pedro and gazed at him with "viva curiosidad," he feels an instinctive repulsion of a comparable intensity vis-àvis Sabel, which causes him to lower his eyes and which will increase as the young woman proves more and more sexually provocative. When in chapter five she enters Julián's room scantily dressed under the pretext of bringing him water, Julián appears literally horrified: "[Julián] no pudo menos que reparar, en una rápida ojeada, cómo la moza venía en justillo y enagua, con la camisa entreabierta, el pelo destrenzado y descalzos un pie y pierna blanquísimos... Cúbrase usted, mujer -murmuró, con voz sofocada por la vergüenza-. No me traiga nunca el agua cuando esté así" (Pardo Bazán 1985: 48). The young woman's uncombed hair, mentioned between two other significant body parts, the breast, suggested by the half-opened shirt, and the thighs, signified by the milky patch of skin, can be related to the virile beard and chest hair of don Pedro, for both are equally charged with erotic connotations; the fact that each instance has the exact opposite effect on Julián indicates clearly the fluidity of sexual desire as well as the priest's instinctive preference. It could be argued that Julián's reaction is that of a righteous individual enforcing the Catholic values of the time, however, his contempt for Sabel is in sharp contrast with the understanding he shows towards the other inhabitants of the Pazos, and in the end does not appear all that Christian: "Desde aquel punto y hora, Julián se desvió de la muchacha como de un animal dañino e impúdico ..." (Pardo Bazán 1985: 48). By characterizing Sabel as an animal, Julián denies her a soul, hence condemning her without any second thoughts, and his half-hearted attempts to forgive her will be quickly foiled by the young woman's continuous provocations. The final rupture between Julián and Sabel occurs when she attempts to seduce him openly by throwing herself onto his bed, pretending to suffer from a sudden malaise: Julián turns surprisingly violent and throws her out in a most callous manner: "Se me va usted de aquí 
ahora mismo o la echo a empellones... ¿entiende usted? No me vuelva usted a cruzar esta puerta... Todo, todo lo que necesite me lo traerá Cristóbal... ¡Largo inmediatamente!" (Pardo Bazán 1985: 49). This less than charitable attitude is in complete contradiction with Julián's self-appointed role as the godly shepherd of the Pazos, as well as with his usual behavior, and supports the same pattern of sexual attraction/rejection which regulated Julián's first encounter with each of them.

Julián's rejection of female sexuality as represented by Sabel must be contrasted with his never-ending indulgence regarding don Pedro, particularly after he discovers the latter's relationship with his maid. Notwithstanding the fundamental sexism of the Catholic church, don Pedro can be considered as guilty as Sabel for living in sin; however, Julián adopts a very lenient attitude towards him, which is in direct opposition with his total lack of compassion regarding Sabel, despite having witnessed don Pedro brutally victimizing Sabel by hitting her with the butt of his rifle. When he decides to leave the Pazos, Julián holds the young woman solely responsible for his defeat: "No, no era Dios, sino el pecado, en la figura de Sabel, quien le arrojaba del paraíso ..." (Pardo Bazán 1985: 75). The narrative perspective is again that of don Julián, as the omniscient narrator gives way to the character's inner discourse; it is Julián who reaches the conclusion that Sabel is responsible for all evils at the Pazos, ironically seen as a "paradise". Hence, Julián envisions his happiness exclusively in function of Sabel's presence or absence, as if the negative influence of Primitivo, which permeates the entire atmosphere of the Pazos, or the disastrous state of the archives, which denotes the decay of the house of Ulloa's entire history and hence possible future, had no bearing upon his perception of the situation. At this point, the figure of Sabel appears as that of a rival, upon the elimination of whom depends the entire stability of Julián's happiness, as denoted by the word "paraíso".

Julián's subconscious attraction towards don Pedro becomes apparent when he is asked to select a suitable bride among the daughters of don Manuel Pardo de la Lage. Feal Deibe's statement, "[Julián] Considera (sin razón) que Nucha sería una buena mujer para don Pedro, y así aconseja a éste casarse con ella" (Feal 1987: 216), is somewhat surprising since the text presents the official reasons for Julián's choice in chapter 10, under the form of an inner monologue triggered by don Pedro's inquiry regarding the respective merits of the four sisters and with Julián as the predominant focalizer:

¿Cómo revelar la manía de la señorita Carmen, empeñada en casarse . . con un estudiantillo de Medicina, un hijo de nadie . . . ? ¿Cómo divulgar que la señorita 


\section{Tribuna \\ MUSEO EMILIA PARDO BAZÁN}

Manolita hacía novenas a San Antonio para que don Víctor de la Formoseda se determinase a pedirla, Ilegando al extremo de escribir a don Víctor cartas anónimas, indisponiéndole con otras señoritas cuyas casas frecuentaba? $\mathrm{Y}$, sobre todo, ¿Cómo indicar ni lo más somero y mínimo de "aquello" de la señorita Rita que, maliciosamente interpretado, tando podía dañar a su honra? Antes le arrancasen la lengua. (Pardo Bazán 1985: 96-97)

Rita's elusive fault is evoked again at the end of the chapter, in the "casino", as one of the customers nonchalantly remarks that "Las chicas por el estilo de Rita siempre encuentran su media-naranja en un forastero" (Pardo Bazán 1985: 102). It is most likely that Rita has committed the unspeakable, "aquello", and that she is no longer a virgin, which explains Julián's horrified tone and subsequent choice. However, it can be argued that his decision goes against the welfare of both Rita and don Pedro, for allowing Rita to marry her cousin would both save her reputation and do a great favor to Julián's protector, don Manuel Pardo. Furthermore, it would also satisfy don Pedro's natural inclination, for Rita can be considered as a double of Sabel in her figure and her demeanor, as well as in the sexual desire she arouses in him: "No lograba el marqués vencer la irritante atracción que le llevaba hacia Rita" (Pardo Bazán 1985: 99). "Irritante" in this context has clear sexual undertones, and although don Pedro, as a mistrustful out-of-towner, vaguely senses some kind of trap, there is no doubt that Julián's advice determines his choice of bride. In the economy of the narration, and knowing don Pedro's sensual appetite and lack of character, his physical attraction towards Rita would have surely decided his choice without Julián's intervention, for it appears to be almost irresistible: "Al estrecharla, don Pedro no pudo dejar de notar las bizarras poroporciones del bulto humano que oprimía. ¡Una real moza la primita mayor!" (Pardo Bazán 1985: 84). The word "bulto", like "cacho" or "pedazo" earlier, suggests an objectification of the subject who inspires desire, and the following exclamation marks can be construed as the signs of spontaneous physical attraction. Don Pedro is clearly able to envision the future of his name through her, hence conceiving Rita as an ideal spouse: "¡Soberbio vaso, en verdad, para encerrar un Moscoso legítimo, magnífico patrón donde injertar el heredero, el continuador del nombre!" (Pardo Bazán 1985: 88). The exclamation marks express the same level of instinctive enthusiasm as before, and are again related to a physical contact, as the word "injertar" clearly denotes.

Julián chooses the most asexual of all four sisters, Nucha, by opposition to the overly sexual Rita who represents another Sabel, to serve his own

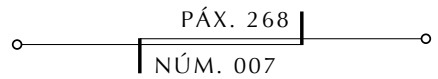


attraction towards don Pedro and protect his desire from the threat of another rival. Nucha not only represents the negation of female sexuality, but she can also be seen as the feminine double of Julián, albeit strictly at a subconscious level, and her sexual ambivalence as a woman mirrors that of Julián's as a man. Echoing Julián's religious vocation, the text often compares Nucha to the Virgin Mary (Pardo Bazán 1985: 148, 172), and she is indeed as close as possible to the Immaculate Conception in the motherly qualities that she displayed with her younger brother, Gabriel, ("Una madre no hiciera más") (Pardo Bazán 1985: 97). Furthermore, she shows no interest towards men in general and seems utterly impervious to her cousin's charm, hence being the perfect spouse for Julián since she implies the substitution of the sexually meaningful Sabel by a feminine sensual void.

Upon their return to the Pazos, Julián increasingly identifies with Nucha, living what could be seen as a vicarious spousal relationship with don Pedro. His relationship to Nucha's daughter, "la nené", is particularly indicative of his identification to Nucha, for not only does he faint when she is born, but he seems to perceive her as if she were his own child: "Estaba dormida... Julián no se cansaba de mirarla así" (Pardo Bazán 1985: 168-69); "No se cansaba de admirarla, de devorarla con los ojos, de considerar sus pupilas, líquidas y misteriosas, como anegadas en leche, en cuyo fondo parecía reposar la serenidad misma" (Pardo Bazán 1985: 177). As the situation in the Pazos regresses to its original state of disarray, Julián proves unable to leave, mainly because of "la nené": "No podía explicarse a si mismo el gran sacudimiento interior que le causaba pensar que no volvería a cogerla en brazos" (Pardo Bazán 1985: 179-80). Julián's final decision to escape with Nucha and the nené does not represent an attempt on his part to replace don Pedro, but rather his second defeat when confronted with Sabel's sexual power over the object of his desire. In this sense, his identification with Nucha is complete and has been materialized through the existence of "la nené".

At a symbolic level, and pre-figuring one of psychoanalysis' main staples, the scene of the spider and the subsequent dream of Julián at the end of chapter 19 clearly illustrate his homosexual desire towards Pedro as well as his subconscious identification with Nucha. While attempting to absorb himself in some edifying readings before going to bed, Julián is alarmed by a horrific scream and runs towards its source, Pedro and Nucha's apartment: "Sí, era la escena misma, tal cual se la había figurado él... Nucha en pie pero arrimada a la pared,...; enfrente, su marido, blandiendo un arma enorme... Julián se interpuso entre los dos" (Pardo Bazán 1985: 187). The association 
between the "arma enorme" and a phallic symbol is quite evident and has already been pointed out elsewhere ${ }^{8}$ : hence, by instinctively interposing himself between the body of Nucha and Pedro's formidable weapon, Julián is offering himself to penetration, effectively substituting himself for Nucha. The reason for the alarm was in reality a spider which Pedro was attempting to kill with his boot. However, Julián has been so impressed by the scene that he re-creates it in his dream that very night, transfiguring its main elements: Pedro becomes a knight in armor about to crush him with an iron boot, and in spite of his terror, Julián does not attempt to avoid him: "Éste [Julián] no hacía ningún movimiento para desviarse y la bota tampoco acababa de caer; era una angustia intolerable, una agonía sin término" (Pardo Bazán 1985: 189). This anxiety can be interpreted as the crescendo of sexual desire, and as the knight becomes St. George defeating a spider-like dragon, Julián feels himself penetrated by his tormentor's lance: "Brillante y aguda, la lanza descendía, se hincaba, se hincaba... Lo sorprendente es que el lanzazo lo sentía Julián en su propio costado... Lloraba muy bajito, queriendo hablar y pedir misericordia; nadie acudía en su auxilio, y la lanza le tenia ya atravesado de parte a parte..." (Pardo Bazán 1985: 190)9. The repetition of the verb "hincar" in a progressive past tense such as the imperfect suggests a sexual motion and Julián's silent moaning and passive attitude complete the representation of a symbolic penetration. Julián eventually identifies with the spider, which semiotically is not without erotic charge for it is described as "un monstruoso

\footnotetext{
8 "The fact that Pedro is brandishing 'an enormous weapon' is enough to make the most hardened anti-Freudian reader smirk" (Hart 2001: 219).

9 Stephen M. Hart considers Julián's identification with the dragon-spider a "surprising role reversal" (2001: 219). However, when read in the light of Julián's homosexual desire for don Pedro, this metamorphosis, far from being surprising, becomes selfexplanatory: Julián becomes naturally the target of Pedro's "arma enorme", that is the spider which he originally mistook for Nucha. By applying Gender theorist Eve Kosofsky Sedgwick's view of the Gothic, as described in The Coherence of Gothic Conventions, Hart identifies key elements of the genre in Los Pazos such as "the trembling sensibility of the heroine and the impetuosity of her lover" or "the tyrannical older man with the piercing glance." (Sedgwick, Coherence, qtd. in Hart 2001: 216) and concludes that there exists a "homosexual relationship" between Nucha, "the female," and Julián, "the feminine" (2001: 225). Although some narrative paradigms of Los Pazos could doubtlessly be construed as gothic, such as the scene in the chapel in chapter 27 , it is however difficult to conceive Julián having the "impetuosity" of a young lover, as it is to discern much romantic "trembling sensibility" in the asexual Nucha; Pedro, far from being a "tyrannical older man" who needs to use his power to enslave the "heroine" is on the contrary physically attractive and sexually desirable. The mechanisms of desire at play in Los Pazos are hence more complex and less structurally predictable than those of the typical gothic narration as conceptualized by Sedgwick.
} 


\section{Tribuna}

vientre columpiado en ocho velludos zancos" (Pardo bazán 1985: 187); the word "vientre" suggests nudity as well as maternity and logically underlines Julián's identification with Nucha as Pedro's spouse; the swinging move can be associated with the motion mentioned earlier and the velludos zancos refer to the erotically charged notion of hair and to that of legs, which are metonymically related to sexuality ${ }^{\text {io }}$.

Julián's oniric representation of homosexual desire echoes St.Sebastian's martyrdom, which according to Richard A. Kaye can be seen as "at once a stunning advertisement for homosexual desire (indeed, a homoerotic ideal), and a prototypical portrait of tortured closet case" (qtd. in Goldman). Both the martyrdom of St. Sebastian and Julián's dream are located within the Catholic imaginary universe and contain similar narrative motifs: Julián and St. Sebastian are deprived of mobility, and the arrows which penetrate St. Sebastian have become the lance of St. George penetrating Julián. Since Julián is the dominant focalizer in the depiction of his dream, his perception can indeed be associated to that of a "tortured closet case," prisoner of both his desire and his impossibilty of externalizing it.

The final chapter of the novel shows Julián as he returns to the church of Ulloa after having been exiled by his superiors to a remote community for an entire decade. The priest appears más varonil (Pardo Bazán 1985: 288), and this change foreshadows the position he will occupy vis-à-vis his servant in the continuation of Los Pazos de Ulloa, La Madre Naturaleza. Although Julián has become a secondary character in La Madre Naturaleza, which tells mainly of the relationship between Perucho and his half sister Manuela, we find a substantial narrative digression in chapter 18 which introduces the priest's past history and present situation, and begins by echoing the same rejection of women that we have observed in the preceding novel:

El cura vivía con un criado, y no pisaba los aposentos otro pie femenino sino el de las mozuelas que en Pascua florida venían a traer las acostumbradas cestas de huevos... Al encontrar a Goros [the servant] el cura de Ulloa resolvió el problema que él juzgaba tan arduo: arreglar la vida práctica, sin admitir en casa mujeres. (Pardo Bazán 1973: 167)

Io In don Pedro's view, Nucha's hair is her only attractive physical feature ("Es algo bizca... Y flaca... Sólo tiene buen genio y buen pelo" [Pardo Bazán 1985: 97]), which further reinforces the sexually charged semiotic code of hair throughout the text, for Pedro's perception and appreciation of women is mostly, if not exclusively, physical.

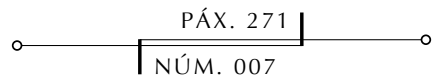


As pointed out by Samuel Amago in "The Form and Function of Homosocial Desire in La madre naturaleza," Julián's and Goros' roles are "clearly described: Julián represents the traditional conception of the male head of household and Goros represents his feminized conjugal "partner" (Amago 2001: 59). Julián is now the male figure in a mono-gendered household, where his servant fulfills the role traditionally reserved to women. The priest's androgyny put forward throughout the previous novel has been transferred to the character of Goros who is explicitly depicted as such in the text: "uno de esos ... seres universales y andróginos que reúnen todas las buenas cualidades del varón y de la hembra" (Pardo Bazán 1973: 167). Goros' tasks around the house are for the most part resolutely of a feminine nature, for he cooks and cleans for Julián, as well as mends his clothes, and the description of their daily routine corresponds indeed to that associated to the traditional representation of a husband and wife's relationship: "Mientras su amo rezaba, leía o asentaba alguna partida en el registro parroquial, Goros se dedicaba a guisar la comida" (Pardo Bazán 1973: 168). As if to prevent any ambiguity, the text itself concludes its presentation of the couple by reinforcing the notion of "hogar":

Si por hogar se entiende no la asociación de seres humanos unidos por los lazos de la sangre para la propagación y conservación de la especie, sino el techo bajo el cual viven en paz y en gracia de Dios con cierta afectuosa comunicación de intereses y servicios, el cura de Ulloa habia reconstruido con Goros el hogar que perdiera al fallecer su madre. (Pardo Bazán 1973: 169)

The word "hogar" introduces and ends the description of an alternative household where gender and genderization are naturally dissociated but which is presented nonetheless as a highly functional binary structure, as if the only distinction existing between a traditional union and that of Julián and Goros resided solely in the biological need to reproduce; indeed, the use of the word "especie", borrowed from the semantic field of zoology, further underlines, if not denounces, the arbitrary nature of the normative sex/gender association carried by the notion of marriage.

Contrary to what one may suppose, sexual tension is not altogether absent from this otherwise highly platonic union, and we can find its semiotic traces in Goros' obsession for vulgar innuendos regarding the ambiguous relationship between priests and their female servants, a customary target for popular salacious jokes: "Cuando no estaba su amo presente, Goros soltaba la rienda a dos inclinaciones invencibles suyas: decir irreverencias y 
murmurar de los curas y de las amas" (Pardo Bazán 1973: 171). Out of these two defects, the later is described at length as Goros appears to know by heart the entire repertoire of "irreverencias y verdores, todas las coplas sobre el clérigo y el ama" (Pardo Bazán 1973: 171-2) and never misses an occasion to share them in the company of other men. Goros hence lives out his sexuality in purely discursive terms by constantly evoking the sinful adventures of his feminine doubles, as his androgyny merges into a homosocial perception, which rejoins that of Julián in rejecting the sexualized feminine. Such explicit representation of a non-normative union, namely of a unisex domestic dyad symbolized by the word hogar, can be construed as a subliminated evolution of the non-normative desire Julián has shown towards don Pedro throughout Los Pazos de Ulloa, a logical counterpoint which appears more directly related to the events presented in the first novel than to the narrative universe of La madre naturaleza, for, as noted by Amago, "one is hard-pressed to explain the significance of such a detailed description of Julián's life with Goros at the structural and temporal center of the novel" (Amago 2001: 58) ${ }^{\mathrm{II}}$. Thus, what appears to be a narrative diggression in La madre naturaleza is to be perceived as a meaningful complement of the greater narrative syntagm composed by Los Pazos de Ulloa and its sequel, as chapter 18 of La madre naturaleza resolves the homosexual tension between Julián and don Pedro present in Los Pazos de Ulloa into an acceptable homosocial relationship between Julián and Goros.

In the gendered textual heteroglossia of Los Pazos de Ulloa, the character of Julián incarnates the voice of homosexual desire, repressed even to himself but nonetheless pervasive through his actions which condition the outcome of the narrative syntagm. Portrayed as nothing more than a narrative parenthesis

\footnotetext{
II Amago notes that "Julián (...) provides narrative continuity between Los Pazos de Ulloa and its sequel", and forms with Goros "a sort of sexual alternative to the tumultuous heterosexual world that surrounds them"(Amago 2001: 59). Although Amago does not relate the homosocial bond between Julián and Goros to the determining homosexual tension present in Los Pazos de Ulloa between Julián and don Pedro, he does point out however the symbolic value of the "mariposilla" which appears both in the last chapter of Los Pazos de Ulloa and during a homoerotic moment between Gabriel and Juncal in chapter 9 of La madre naturaleza (Amago 2001: 55), and which connotes "same sex desire in several cultural contexts" (Amago 2001: note 3); it is therefore significant to find the "mariposilla" ending her flight in the last chapter of Los Pazos de Ulloa "en un mezquino mausoleo, arrinconado entre la esquina de la tapia y el ángulo entrante que formaba la pared de la iglesia (...)" (Pardo Bazán 1985: 175), for Julian's homerotic desire lies indeed between the walls of the Pazos and the hard angles of Catholic morality, metonymically signified in this passage by the words "tapia" and "iglesia".
} 
in La Madre Naturaleza, his evolution consolidates the notion of a silenced, literally murdered voice, for the text presents the priest no longer as a physical being, but rather as a sheer abstract entity: "Era un rostro mortificado, de esos que se ven en pinturas viejas, donde la sangre ha desaparecido y la carne se ha fundido, ahondándose las concavidades todas, yéndose los ojos, al parecer en busca del cerebro y sumiéndose la boca, que remata en dos líneas severas, jamás modificadas por la sonrisa" (Pardo Bazán 1973: 172-3). Julián is no longer of blood and flesh, and it is significant that this description concludes with the mouth, semiotically related to love and sexuality, and which is reduced here to two severe and lifeless lines, hence connoting the consummated death of desire. The skull like features of his face, suggested by the deepened eye sockets are in direct relationship with the cemetery where Julián spends most of his time, as if he were himself one more element of the graveyard. For Julián indeed belongs to the cemetery of Ulloa, where lie not only the body of his ideal double, Nucha, but also the murdered memory of his subconscious but determining homosexual desire. 


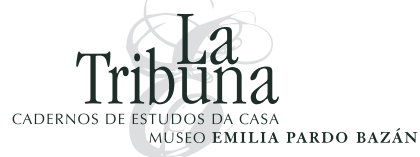

WORKS CITED

- Amago, Samuel (2001): "The Form and Function of Homosocial Desire in La madre naturaleza", Romance Quarterly, 48.1, 54-63.

- Bakhtin, Mikhail M. (1981): The Dialogic Imagination, Ed. Michael Holquist, Trans. Caryl Emerson and Michael Holquist, Austin, U of Texas P, Print.

- Bieder, Maryellen (1990): "Between Genre and Gender: Emilia Pardo Bazán and Los Pazos de Ulloa", In the Feminine Mode: Essays on Hispanic Women Writers, Eds. Noël Valis and Carol Maier, Lewisburgh, Bucknell UP, 131-145. Print.

- DuPont, Denise (2002): "Decadence, Women Writers, and Literary History in Emilia Pardo Bazán's Late Criticism", MLN 117.2: 343-364. Print.

- Goldman, Jason. "Subjects of the Visual Arts: St. Sebastian." glbtq: An Encyclopedia of Gay, Lesbian, Bisexual, Transgender, and Queer Culture. glbtq, Inc, July 4, 2005. Web. 6 March 2010. <http://www.glbtq.com/arts/ subjects_st_sebastian.html>.

- Feal Deibe, Carlos (1987): "La voz femenina en Los Pazos de Ulloa", Hispania, 70. 2: 214-221.

- Foster, David William (1999): Spanish Writers on Gay and Lesbian Themes: A Bio-Critical Sourcebook, Westport: Greenwood.

- "Fresa y chocolate" (1994): Tomás Gutiérrez Alea and Juan Carlos Tabío (Dir.). ICAIC, DVD.

- Giles, Mary E. (1980): "Feminism and the Feminine in Emilia Pardo Bazán's Novels", Hispania, 63. 2: 356-367.

- Harpring, Mark (2006) "Homoeroticism and Gender Role Confusion in Pardo Bazán's Memorias de un solterón", Hispanic Research Journal, 7.3: 195210.

- Hart, Stephen M. (2001): "The Gendered Gothic in Pardo Bazán's Los Pazos de Ulloa", Culture and Gender in Nineteenth-Century Spain, Lou Charnon-Deutsch and Jo Labanyi (Eds), Oxford, England, Clarendon, 216-29.

- Kirkpatrick, Susan (1999): "Gender and Modernist Discourse: Emilia Pardo Bazán's Dulce Dueño", Modernism and Its Margins: Reinscribing Cultural Modernity from Spain and Latin America, Anthony L. Geist and José B. Monleón (Eds.), New York, Garland, 117-39.

- Lindtvelt, Jaap (1981): Essai de Typologie Narrative: le point de vue, Paris, José Corti. 
- Llácer, Eusebio (1991): "Análisis microestructural de Los Pazos de Ulloa", Romance Quarterly, 38. 4: 431-436.

- Pardo Bazán, Emilia (1985): Los Pazos de Ulloa, Madrid, Alianza Editorial.

- Pardo Bazán, Emilia (1973): La Madre Naturaleza, Madrid, Alianza Editorial, 1973.

- Solanas, Juan V. (1981): "Estructura y Simbolismo en Los Pazos de Ulloa", Hispania, 64.2: 199-208.

- Tolliver, Joyce (1994): "Sor Aparición' and the Gaze: Pardo Bazán's Gendered Reply to the Romantic Don Juan", Hispania, 77. 3: 394-405.

- Wietelmann Bauer, Beth (1994): "Narrative Cross-Dressing: Emilia Pardo Bazán in Memorias de un solterón", Hispania, 77.1: 23-30. 